Proc. Estonian Acad. Sci. Geol., 2002, 51, 3, 157-179

\title{
Geological history of Lake Võrtsjärv
}

\author{
Tanel Moora ${ }^{\mathrm{a}}$, Anto Raukas ${ }^{\mathrm{b}}$, and Elvi Tavast ${ }^{\mathrm{b}}$ \\ a Institute of History, Rüütli 6, 10130 Tallinn, Estonia \\ b Institute of Geology, Tallinn Technical University, Estonia pst. 7, 10143 Tallinn, Estonia; \\ raukas@gi.ee, tavast@gi.ee
}

Received 25 October 2001, in revised form 8 March 2002

\begin{abstract}
Lake Võrtsjärv, with a surface area of $270 \mathrm{~km}^{2}$, has a very complicated geological history. Proglacial lakes of different shape and size were formed in the Võrtsjärv Lowland. Due to the tectonic uplift outflows to the west closed in the Early Holocene. At the beginning of the Middle Holocene, about $7500 \mathrm{BP}$, an outflow to the east developed and little by little the lake acquired its present contours. Like many lakes in Europe, Vorrtsjärv has an open eastern (leeward) and a more swampy and overgrown western (windward) bank. The bottom sediments consist mostly of sapropel (gyttja), fine sand and silt. The sediments are thicker in the southern part of the elongated lake basin where the up to $9 \mathrm{~m}$ thick layer of sapropel is usually underlain by $8 \mathrm{~m}$ of lacustrine lime. Gradual rise of water level in the southern portion of the basin is caused by land uplift, the rate of which increases towards the northwest.
\end{abstract}

Key words: glacial lakes, neotectonic uplift, outflows, sapropel, lake marl, floods.

\section{GEOGRAPHICAL AND GEOLOGICAL SETTING}

Lake Võrtsjärv $\left(58^{\circ} 0^{\prime}-58^{\circ} 26^{\prime} \mathrm{N}\right.$ and $\left.25^{\circ} 24^{\prime}-26^{\circ} 0^{\prime} \mathrm{E}\right)$ measures some $270 \mathrm{~km}^{2}$ in area. Its length is $34.8 \mathrm{~km}$, maximum width $14.8 \mathrm{~km}$ (Fig. 1), the length of the relatively straight shoreline $96 \mathrm{~km}$, maximum depth about $6 \mathrm{~m}$, average depth $2.8 \mathrm{~m}$, long-term water-level stand $33.63 \mathrm{~m}$, volume 756 million $\mathrm{m}^{3}$ of water, catchment area $3374 \mathrm{~km}^{2}$. The main tributaries number 21 and include five rivers: the Väike Emajõgi, the Õhne, the Tarvastu, the Tänassilma, and the Rõngu (Fig. 2). The outflow is through the Emajõgi River into Lake Peipsi in the east. Water-level fluctuations in the contemporary lake are significant (e.g. $35.28 \mathrm{~m}$ on 


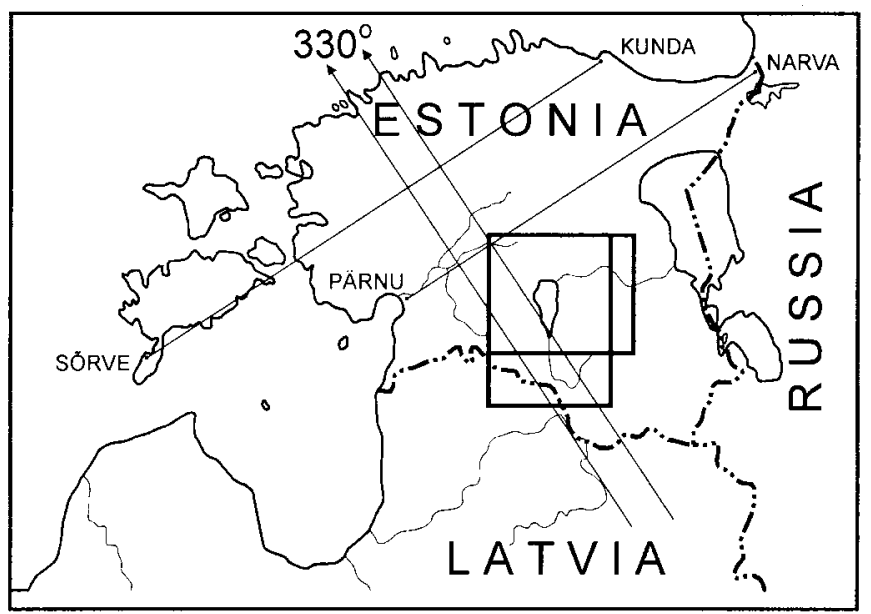

Fig. 1. Location map of the investigated area (in rectangles Figs. 2 and 4). The fastest land uplift azimuth $\left(330^{\circ}\right)$ in Lambert projection is shown with arrows.

26 November 1923 and $32.20 \mathrm{~m}$ on 6 September 1996). The maximum difference of the water table is over $3 \mathrm{~m}$ and the rise during the spring flood up to $174 \mathrm{~cm}$ (Jaani 1973). In 1922, the maximum annual amplitude was $2.2 \mathrm{~m}$. Wide waterlevel fluctuations occurred also in the past, and this hampers the dating and correlation of ancient shorelines.

In the 19th century, the water level in the lake was about a metre higher than at present. In the 1920s, the outlet of the Emajõgi was thoroughly dredged and stone jetties were constructed to block longshore drift hindering the outflow from the lake.

The bedrock, mostly Eifelian sand- and siltstones of the Middle Devonian Aruküla Regional Stage $\left(D_{2}\right.$ ar), is exposed only in some places on the eastern bank, which has a height of $8.5 \mathrm{~m}$ at Tamme. The depression around the lake is covered mainly with glacial and glacioaquatic deposits and peat, in some places with aeolian and alluvial sandy-silty sediments (Fig. 3). The thickness of the Quaternary cover is usually less than $10 \mathrm{~m}$.

The development of Võrtsjärv was controlled by the deglaciation processes and tectonic movements. The contemporary lake has a meridionally elongated configuration. Tilting of shorelines is the result of a more intensive uplift of the northern part of the lake, through which runs also the zero isobase of the land uplift for the last 10000 years (Fig. 4). Due to the uneven neotectonic uplift of the depression, the lake is steadily retreating southward, inundating new areas. In about 2000 years, its northern part will be dry and the southern part swampy. The contours the lake will possibly have at that time are depicted in Fig. 3. 


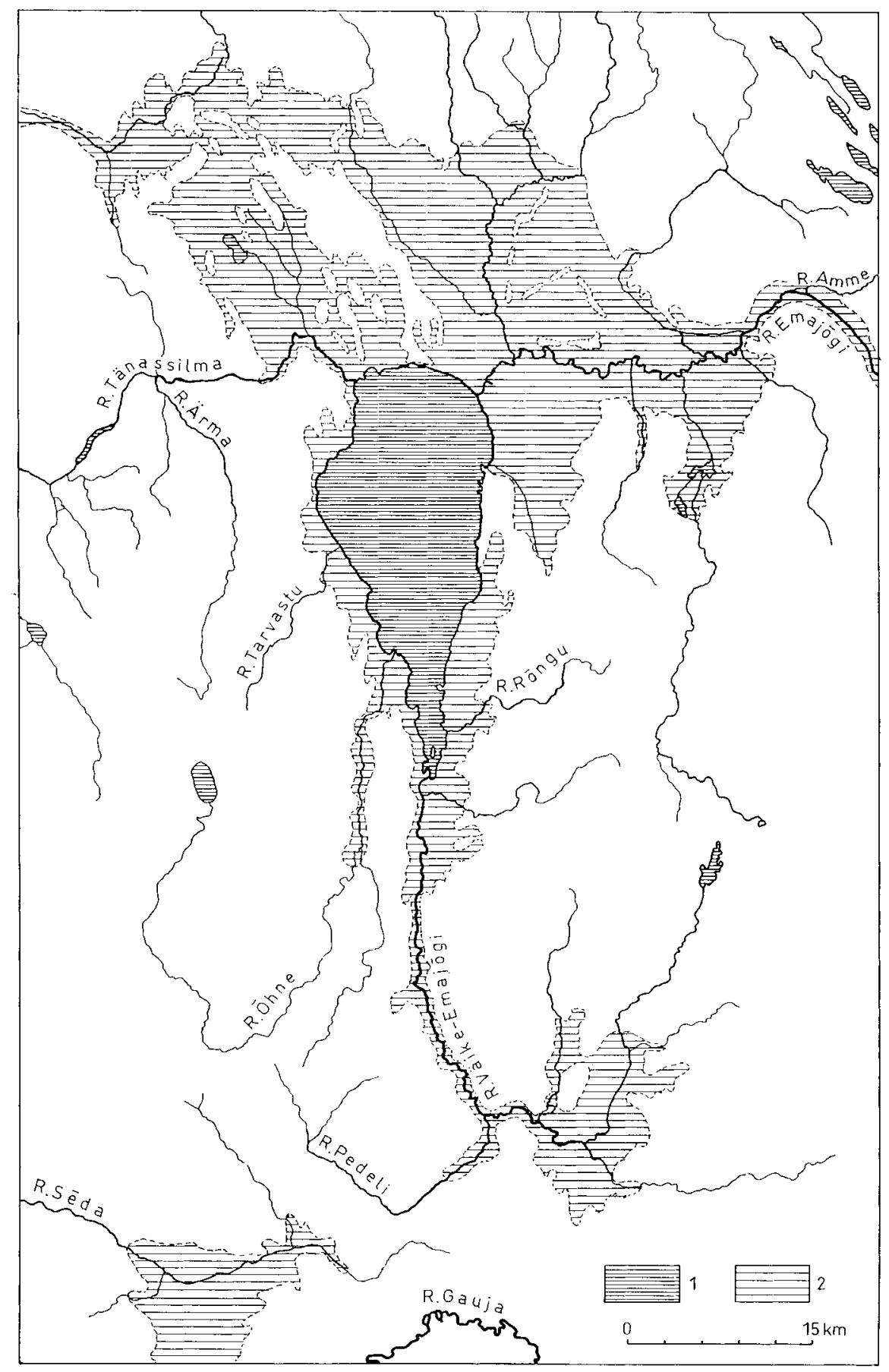

Fig. 2. Contemporary lakes (1) and the distribution of water bodies during the final stage of Ice Võrtsjärv and the initial stage of Ancient Võrtsjärv (2) according to their bottom sediments (varved clay, fine sand and silt). 


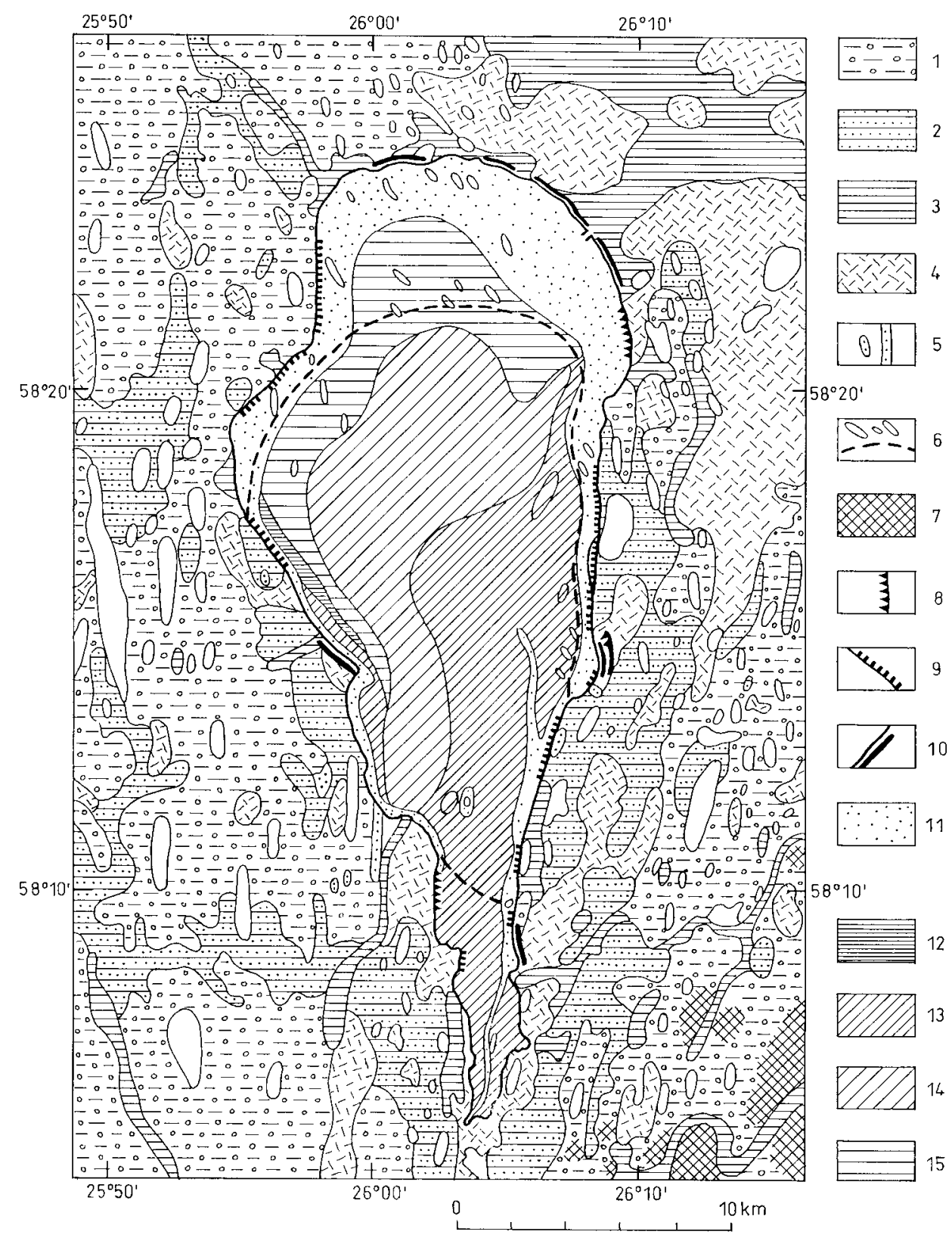

Fig. 3. Quaternary deposits and landforms in the surroundings of Lake Võrtsjärv (in Legend 1-10) after Raukas \& Tavast (1990), and the bottom sediments of the lake (in Legend 11-15) after Varep (1958): 1, till; 2, glaciaquatic deposits; 3, lake or river deposits; 4, peat; 5, aeolian deposits; 6 , drumlins, drumlinoids, and the plausible shoreline of the lake after 2000 years; 7, kames; 8 , bluffs in the peat; 9 , bluffs in the till or in the bedrock; 10 , beach ridges of the contemporary lake; 11 , fine sand and sandy silt; 12 , varved clay; 13 , mud and gyttja; 14, gyttja on the clay; 15 , clayeysilty mud. 


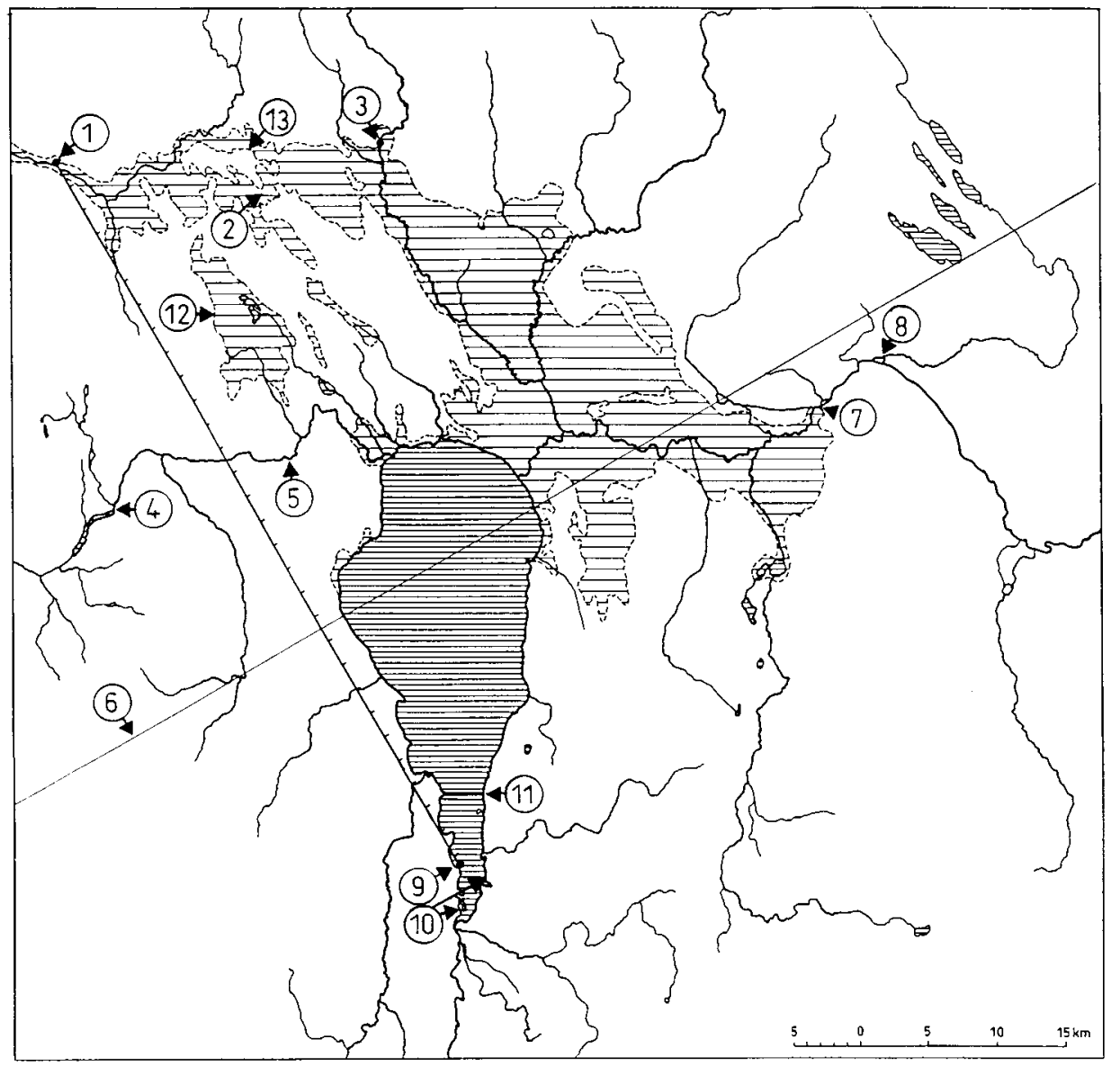

Fig. 4. Distribution of Lake Big Võrtsjärv (sparsely striped areas) and contemporary lakes (densely striped areas). Big Võrtsjärv is contoured on the basis of lake sediments (loamy gyttja with organic matter, lake marl, limy silt, and beach sands). For explanation of 1-9 see Fig. 5. 10, the sites sampled by R. Pirrus and L. Orviku; 11, Haanja-Alapu Nukk transection site; 12, ancient Lake Parika and L. Big Parika; 13, transection site near Lebavere.

\section{THE HISTORY OF RESEARCH}

The first written references to Võrtsjärv were in Henrici Chronicon Livoniae XV:7, XXIV:5, and XXIX:3, compiled in about 1224-27 (Tarvel 1982). Zur Mühlen (1918) summarized the data of earlier research and the results of the extensive fieldwork carried out in the environs of Võrtsjärv in 1911-13. Ramsay (1929) published a scheme where he graphically depicted the differences of the postglacial uplift in the present territory of Estonia, calling special attention to its extent in the southern half of the Võrtsjärv depression. 
The foundation to detailed research into the lake's geology was laid by L. Orviku (1958) and K. Orviku (1973). The latter distinguished several stages in the history of the lake: Glacial Võrtsjärv (Jää-Võrtsjärv), Primeval Võrtsjärv (Ürg-Võrtsjärv), Great Võrtsjärv (Suur-Võrtsjärv), and Present Võrtsjärv (Nü̈̈̈disVõrtsjärv).

During these stages both the lake level and dimensions greatly differed from those at present. In this paper, we use the same stages of the lake but the names are slightly different: Ice Võrtsjärv, Ancient Võrtsjärv, Big Võrtsjärv, and Contemporary Võrtsjärv (Table 1). A short initial phase of Ice Võrtsjärv we have named Small Võrtsjärv.

In the 1980s, the authors of the present paper together with late Reet Pirrus started a complex geological research of the Võrtsjärv depression, including the monitoring of the lake shores, the mapping of its bottom deposits and the geological structure of the surroundings of the lake (Raukas \& Tavast 1990). State monitoring in Estonia gained legal ground in 1993. The monitoring of the beaches of Võrtsjärv was included into this programme in 1994 (Tavast 1998). Many problems related to the history of the lake have remained topical, because the number of geodetic measurements and drillings is too small to provide sufficient evidence for their solution. We hope that the result to be obtained within our projects which started in 2000 will contribute to solving at least some of these problems. This paper is the first one in the series to be published on the subject under discussion.

\section{METHODICAL PROBLEMS}

The history of proglacial lakes in the Baltic Sea area has been studied on the basis of flat levels of different glaciofluvial and glaciolacustrine relief forms (outwash plains, kames, eskers), river terraces and coastal formations of ancient lakes (Raukas et al. 1971). However, the coastal formations are often lacking. Their small size or absence on ancient shores of Võrtsjärv is due to the flat topography, the occurrence of erosion-resistant rocks and deposits, and the shortterm halts of water levels. In the shallow basin, the waves were small and their destructive power inconsiderable. Longshore drift was insignificant and did not contribute to the development of large accumulative coastal formations. The development of both contemporary and ancient coastal formations has been influenced by drift ice. Fine sand, silt, and varved clay, typical of ice lakes, facilitated drawing up the contours of ancient lakes (Fig. 2). Unfortunately, after a rapid fall of lake level, varved clays, particularly in the southern part of the ice-dammed lake, remained dry and were partially eroded. The varved clays discovered during geological drilling under glaciofluvial deposits in the valleys of the Väike Emajõgi and Pedeli rivers and in the town of Valga may partly originate from earlier glaciations. In the coastal zone and areas around the inflows to the lake, the varved clay is often covered with a thick layer of silt or sand. 
Table 1. Main stages of the development of Lake Võrtsjärv on the stratigraphical column of the Late-Glacial and Holocene deposits of Estonia. After Raukas et al. (1995).

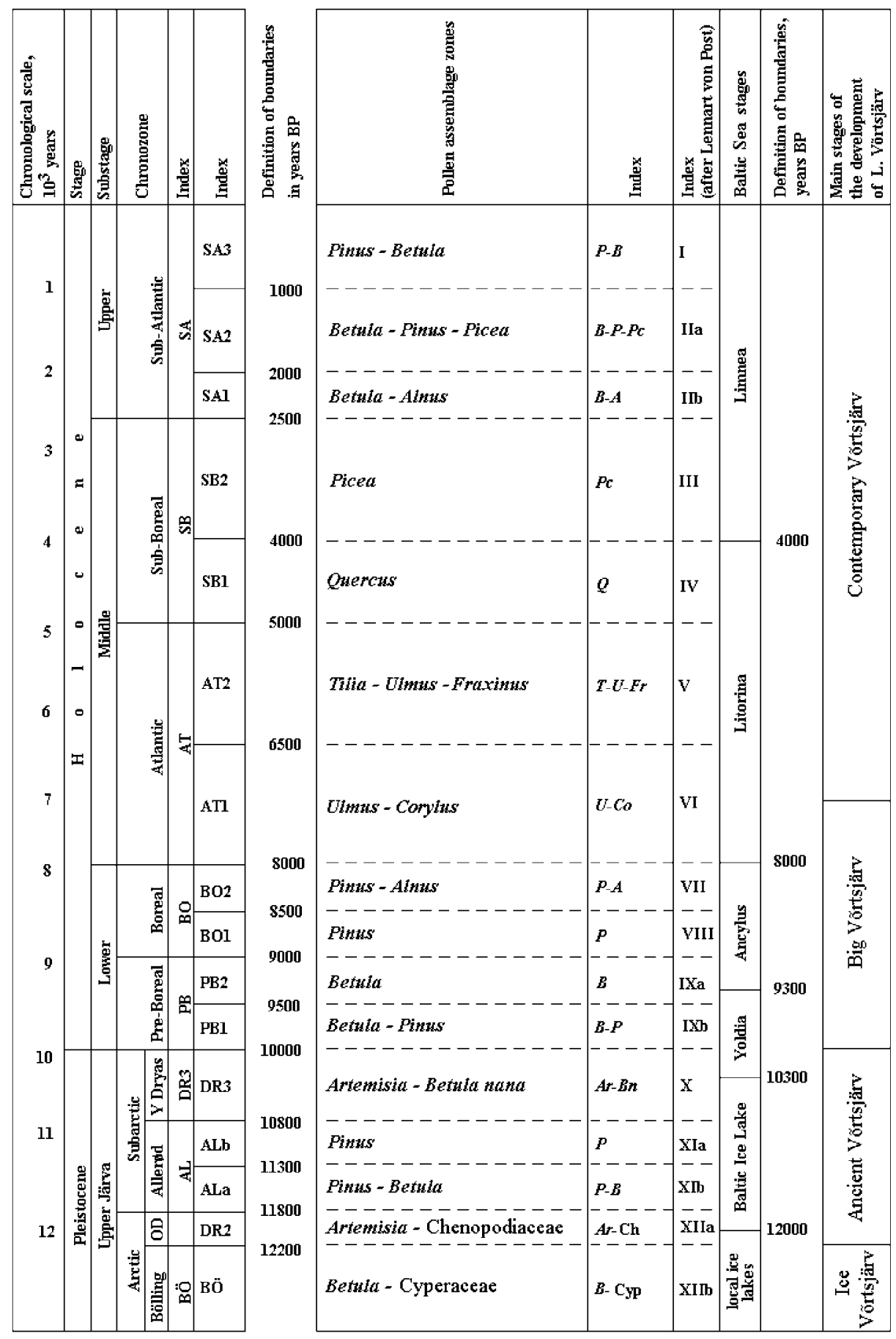


The hitherto known reconstructions of ancient water bodies are, in many respects, highly hypothetical, because they are frequently based on the contemporary topography. However, due to the uneven tectonic movements of the threshold, the position of the shorelines has changed beyond recognition since the Late-Glacial. In order to avoid repeating the delusions made by earlier investigators, a spectrum of maximum and minimum uplifts was compiled using an azimuth of $330^{\circ}$, pointing out the most important thresholds (Figs. 4, 5). The azimuths obtained by earlier investigators were a bit different, possibly because these were calculated on the basis of the northwestern part of Estonia and on the topographical maps of different projections. For instance, Kents (1939), who was the first to calculate the land uplift gradient for Estonia, used the topographical map of the General Staff of Russia. For the time interval from the Ancylus Lake maximum up to the present (see Table 1), he calculated the land uplift gradient $326^{\circ}$. We marked the locations of profiles at Sõrve and Kunda, on which Kents based his measurements, to the Lambert map and obtained an azimuth of $330^{\circ}$ (Fig. 1). Pärna (1962) used the spectrum line $335^{\circ}$ for the local ice-dammed lakes and $326^{\circ}$ for the Baltic Ice Lake. He used the same topographical maps as Kents. For the same stages, Kessel (1961) preferred the spectrum lines $324^{\circ}$ and $316^{\circ}$, respectively. However, afterwards, in cooperation with Raukas she returned to older azimuths used by Pärna (Kessel \& Raukas 1979). The last authors also applied an azimuth of $326^{\circ}$ to the Holocene stages of the Baltic, except the Limnea Sea stage $\left(320^{\circ}\right)$.

The $330^{\circ}$ azimuth on the Lambert projection maps seems to fit best for Central Estonia as well. Namely, the data obtained through the study of sediments of ancient lagoons at Narva and Paikuse (Sindi) suggest that during the time interval from the Litorina Sea maximum up to the present (see Table 1) these areas show the same intensity of land uplift. Therefore, relying on the previous speculation, a conclusion can be drawn that the azimuth of the most rapid land uplift on the topographical map of the Lambert projection has been $330^{\circ}$ during the last 6500 years for the NW half of Estonia (Fig. 1). Our land uplift gradient $330^{\circ}$ of the Võrtsjärv Depression for the last 10000 years was formed accidentally by joining the two most distant boring sites - Navesti and Naritsa (Figs. 4, 5).

The current state of stratigraphic studies does not permit us to make fully reliable palaeogeographic reconstructions for the Pleistocene stage of the lake history. For many years, pollen analysis was the basic tool in deglaciation studies, however, it did not provide direct data for such an event. Interstadial or interphasial layers occur frequently between different till beds in South and Central Estonia, but they have no clear palynological characteristics and probably contain a lot of material redeposited from sediments left behind by older interglacials or interstadials. The spore and pollen in Late-Glacial deposits above the till beds in the Võrtsjärv area suggest severe climatic conditions. Local vegetation had just started to develop and the concentration of pollen originating from earlier climatic stages and redeposited in sediments was also high. On the other hand, pioneer vegetation undoubtedly already existed in the dead ice topography, but in clay 


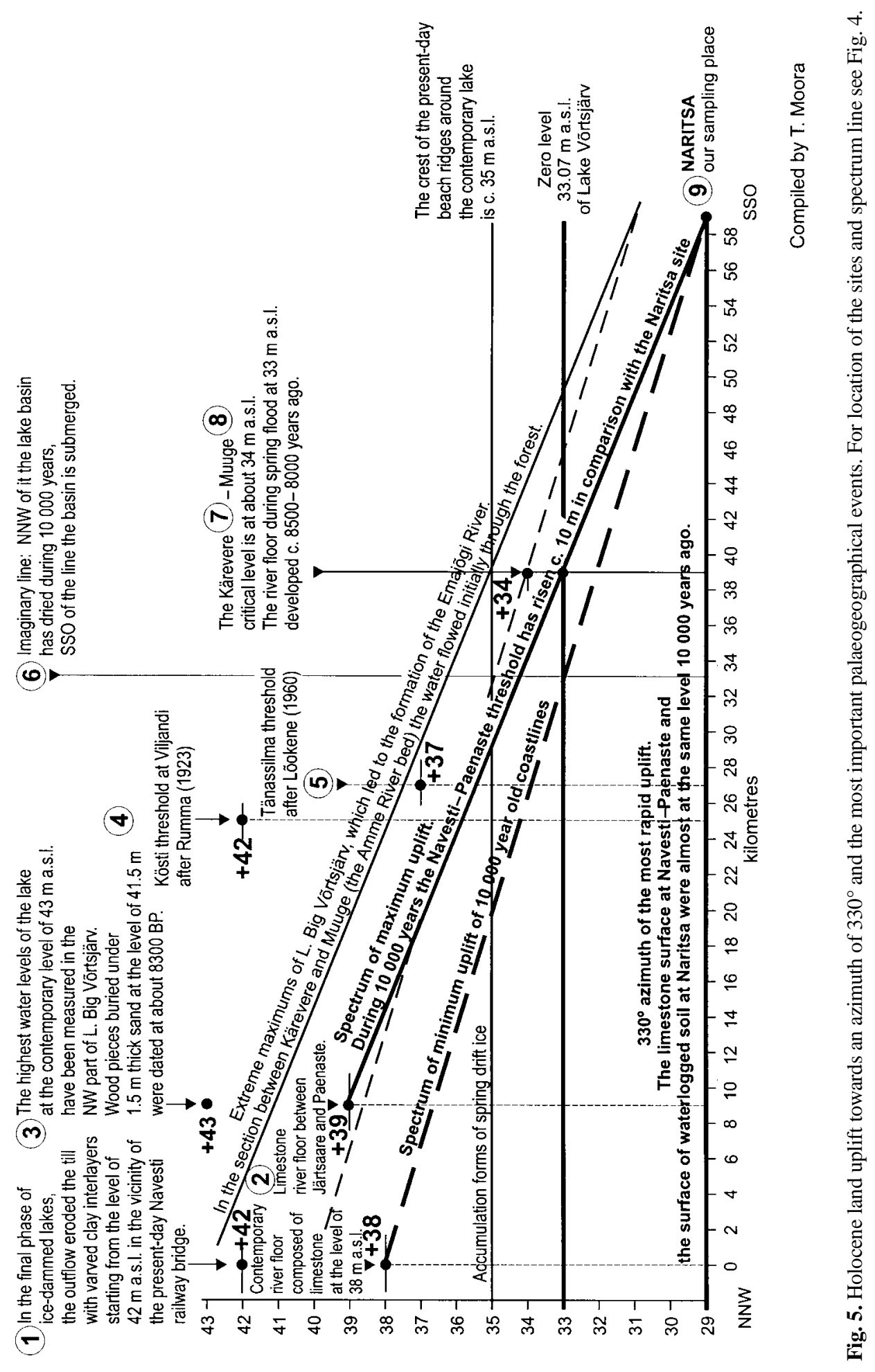


and silt the older pollen grains are mixed with younger ones. That is why the Late-Glacial sediments in this region do not reveal any clear palynological characteristics. We are going to resume this theme again when dealing with Ancient Võrtsjärv. Accumulation of organic-rich sediments in the small lakes of southern Estonia started 10 300-10 $200 \mathrm{BP}$, replacing the accumulation of sand, silt, and clay that were clearly prevailing during the Late-Glacial (Pirrus \& Raukas 1996).

A big breakthrough in dating was the elaboration of the ${ }^{14} \mathrm{C}$ method. We have made wide use of this method since 1960 , when a radiocarbon laboratory was founded in Tartu. Nevertheless, the research has not progressed so rapidly as was initially expected. In our studies, we have also used the TL and OSL methods, but the accuracy of the dates obtained has not been high enough to allow us to draw reliable palaeogeographic conclusions. As a result, most of the correlation schemes are still rather speculative.

\section{PREGLACIAL AND GLACIAL HISTORY OF THE LAKE BASIN}

The development of the cuesta-like bedrock topography in Estonia has been affected by different geological processes. In the course of the long-term preQuaternary period, it was mainly controlled by erosional processes. At the beginning of the Pleistocene, the flat Võrtsjärv Depression formed between the South Sakala bedrock elevation (below the present-day morainic Sakala Upland) and the Otepää bedrock elevation (below the current Otepää Heights with a thick Quaternary cover). The depression was later over-deepened by glaciers, which removed a layer of the Silurian and Devonian bedrock, some tens of metres thick (Tavast \& Raukas 1982). During all glaciations, the area of Võrtsjärv remained in an ice-lobe depression, where glaciers disintegrated into several ice tongues moving at different speeds and forming drumlins (Fig. 3).

Estonia's area was freed from the continental ice during a time span of about 2000 years. The ice cover began to retreat from the southernmost part of the present-day Estonia at least $13000{ }^{14} \mathrm{C}$ years ago. The area, which is now Estonia, was finally cleared of ice about $11000{ }^{14} \mathrm{C}$ years ago (Raukas 1986). The deposits overlying the till started to accumulate in South Estonia in the Older Dryas (OD) or Allerød (Table 1). The history of deglaciation is genetically connected with the ice-dammed lakes, which developed in front of the ice margin or in the body of melting dead ice.

Our vision of the evolution of Lake Ice Võrtsjärv is presented in Fig. 6. When the ice flow between the Sakala and Otepää heights stagnated, the resulting meltwater started to accumulate in the fracture-rich area of the southern part of the Võrtsjärv Depression. As a result, the rate of ice melting in lower-lying areas increased as well. This hypothesis is based on the different distribution of sediments in the area where two types of Pleistocene sediments of entirely different genesis can be distinguished (depicted on the map with the jagged line; line 2 in 
Fig. 6). In this area the parent rock of soils is mostly sandy-loamy, occasionally silty-loamy basal till. Outside this area, the Quaternary cover has a more complicated structure. The till is usually overlain by glaciofluvial sediments, but in the Laatre and Strenči depressions (Fig. 6, L and S) it is covered with glaciolacustrine sediments. In Small Võrtsjärv (Fig. 6, V-V), which reached as a narrow wedge into the Väike-Emajõgi Valley (Fig. 2), the water level was very unstable and in summer it was clearly a fluvial body of water. This conclusion is supported by the occurrence of eskers, delta plains, and kame fields between the areas marked with the jagged line on our map (Fig. 6, V-V).

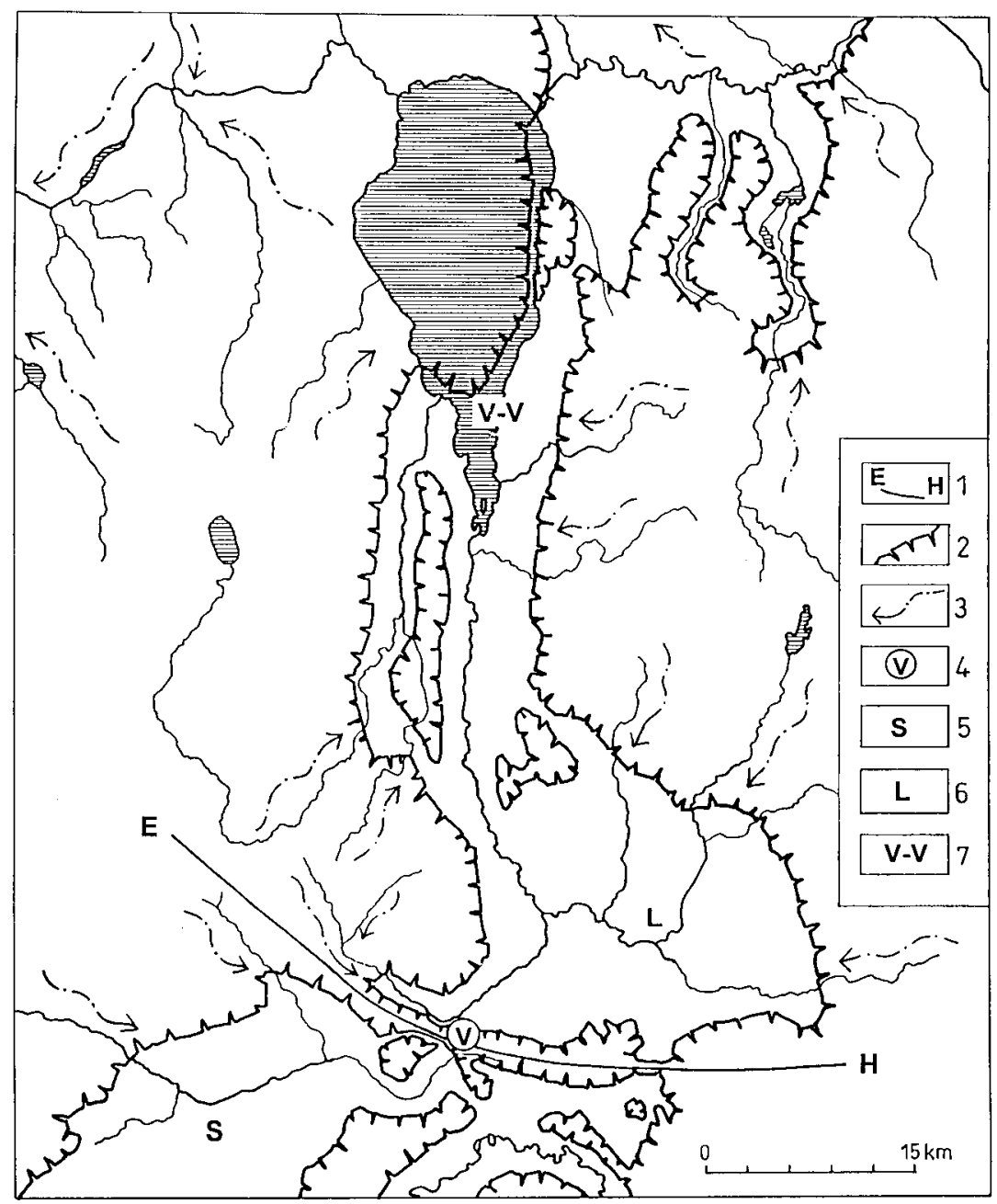

Fig. 6. Initial stage of Lake Ice Võrtsjärv. 1, water divide after Tammekann (1932); 2, melting ice cover with dead ice blocks; 3, direction of meltwater flow; 4, town of Valga/Valka; 5, Strenči Ice Lake after Aboltynsh et al. (1974); 6, Laatre Ice Lake after Raukas et al. (1971); 7, Lake Small Ice Võrtsjärv. 
When exactly the connection between the ice-dammed lake in the Peipsi Depression and Ice Võrtsjärv developed is not yet clear. According to the figures compiled by Hang (2001), Peipsi ice-dammed lake could also have drained towards the northwest. If at that time there was a connection between these lakes, the level of Ice Võrtsjärv was controlled by the water level in Peipsi ice-dammed lake.

Kajak (1959) who studied the Väike-Emajõgi Valley, advanced a hypothesis that up to a height of $50 \mathrm{~m}$ above the contemporary sea level the meltwater in the Väike-Emajõgi Valley (Fig. 2) flowed to the south - over the so-called Valga threshold (Fig. 6, V) into the Gauja Valley. None of the Latvian geologists who studied the evolution of the Gauja Valley (Aboltynsh 1971) and Strenči icedammed lake (Aboltynsh et al. 1974) have made a mention of the meltwater flow or the existence of the threshold. The authors of this paper also suppose that after the retreat of the glacier from the Gauja line the meltwater never flowed to the south from the Härgmäe-Hargla water divide (Fig. 6, E-H) distinguished by Tammekann (1932). In all likelihood, the meltwater which flowed into the Laatre ice-dammed lake and the Väike-Emajõgi Valley from the direction of the Otepää Heights (Tammekann 1932; Kajak 1959) found its way out through the crevasses developed in the ice, at first probably somewhere in the northwestern part of the Võrtsjärv Depression. We have a reason to believe that due to the glacier dynamics these outflows were closed from time to time and in the dammed area the ice cover started to melt rapidly. Evidence is derived from the occurrence of varved clays in the Tänassilma-Viljandi valley, particularly in the Navesti Depression, where in the vicinity of the railway bridge varved clay lenses can be found between till layers.

The final stage of Ice Võrtsjärv and initial stage of Ancient Võrtsjärv (Fig. 2) have again been reconstructed on the basis of the distribution of bottom sediments of the mentioned lakes, varved clays in Ice Võrtsjärv and sand and silt in Ancient Võrtsjärv. As long as the dynamics of glaciers in the study area cannot be established on the basis of sediment analysis, this is the only possible approach to clearing out the evolution of the lake. Once again, we would like to stress that in Ice Võrtsjärv the water level must have fluctuated greatly in the course of years. In the area depicted in Fig. 2 we have established several coastal formations small coastal ridges and short terraces. However, only after detailed in situ studies it can be stated with confidence which of those belong to Ice Võrtsjärv and which to Ancient or Big Võrtsjärv.

Unfortunately our knowledge of the sediments forming the Quaternary cover north of the Emajõgi River is rather incomplete. An ice-dammed lake may have formed, in the first instance, in the northeastern part of the Võrtsjärv Depression, in the area extending up to the Kärevere threshold where varved clays have been found. A thick bed of varved clays (up to $8.5 \mathrm{~m}$ ) in the southern part of Põltsamaa Bog may also serve as an evidence of this lake. Frequently, these clays lie straight on the bedrock. It is possible that before the accumulation of varved clays a strong flow of water moving to the northwest washed away the thin till cover overlying 
the bedrock layers as it happened in the Navesti Valley. The level of Ice Vorrtsjärv was controlled by the glacier dynamics simultaneously in several places, including the Tänassilma-Viljandi-Raudna valley system, Navesti Valley, and Emajõgi Valley. It would be incorrect to assume that the meltwater did not find a way out from the Vorrtsjärv Depression. For instance, if the channel in the ice cover above the Tänassilma Valley closed even for a short time, the water of the ice-dammed lake rose to a height of $45 \mathrm{~m}$ a.s.l. and flowed to the west on the lower reaches of the Ärma River (Figs. 2, 6). Once again, we would like to point out that in the Tänassilma Valley the meltwater flowed to the west, cutting a deep channel into the till. The same process took place in the Navesti Valley. However, there are stretches, several kilometres in length, where the water eroded hollows and funnels into the limestones and dolomites of the bedrock. Afterwards, these came to be buried under fluvial sand, till or varved clay. This shows that both outflows to the west were temporarily closed. Peipsi ice-dammed lake drained more than 13000 varve-years ago (Hang 2001), and during a certain period there must have been a meltwater flow from the Võrtsjärv Depression to the east. Probably, this took place at the beginning of the ice-dammed lake formation. Already Ramsay (1929) seems to have reached this conclusion.

To illustrate the above, we are going to present in this paper only the results obtained through analysing the bottom sediments of an outflow branch from the Võrtsjärv Depression into the Navesti Valley. The sampling point was between Lebavere and Paenaste villages (Fig. 4, point 13). In or under the melting ice, obviously in an ice crevasse, the meltwater eroded a channel into the basal till (Fig. 7). When and in which direction the eroding water first flow is not yet clear. In the Gulf of Riga, a larger body of water existed already at the beginning of the Allerød (Stelle et al. 1995), i.e. almost $12000{ }^{14} \mathrm{C}$ years ago. But, originally, the water may also have flowed along the Emajõgi ancient valley in the direction of ice-dammed Lake Peipsi, which according to Hang (2001), must have sunk down already more than 13000 varve-years ago. At that time, the only possible direction could have been northeast.

After the water flow in the channel between Lebavere and Paenaste abated, the bottom of the channel was covered with a $1 \mathrm{~m}$ thick layer of fine sand. Later ice crevasses or the outflow from the lake closed somewhere in the area of the Navesti railway bridge, the waterflow stopped, and the water level rose considerably as the varved clays settled down on the fine sand (see Fig. 7). When the water level dropped, the varved clay was, in its turn, covered with a thick layer of loamy silt. Once again, a fluvial period followed, in the course of which the upper part of the loamy silt was carried away. By the beginning of the Holocene, the outflow from the Võrtsjärv Depression proceeded mainly through the southern branch (Fig. 4, point 2). The fen peat started to form in the channel, and spring (temporary) floods flowed there towards the Navesti River along swampy woods. Due to a slight tilt of the surface in this direction, the area was overgrown with fen peat already 9500 years ago (see ${ }^{14} \mathrm{C}$ date and pollen diagram in Fig. 7). 


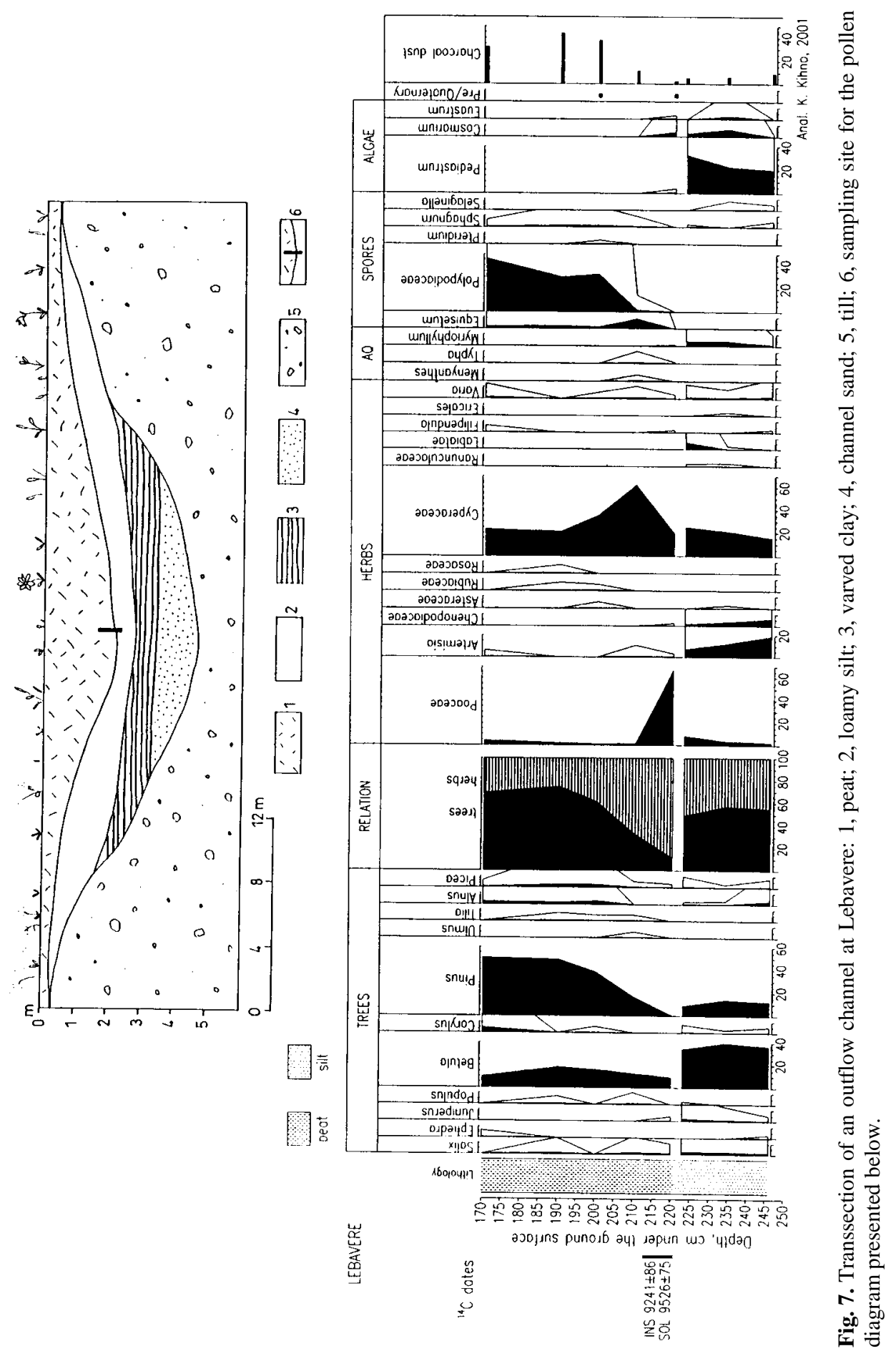


Based on our preliminary analysis, we dare to say that during the setting of loamy silt, the first vegetation at the ice-free sites or till cover on dead ice may have appeared already in the Older Dryas. But, certainly, it existed in the Allerød. Unfortunately, in our diagram, the pollen of Betula nana and the other Betula species have not been calculated separately. According to S. Hiie (pers comm.), the seeds of Betula nana and other macrofossils of this plant can be found in the loamy silt. An analysis, where Betula nana and the amount of other Arctic plants have been determined, is still under way.

\section{ANCIENT VÕRTSJÄRV}

For the stage which started from the final lowering of water level and development of outflow into the Baltic Ice Lake in the Pärnu Lowland (Ramsay 1929; Pärna 1962), we have used the name Ancient Võrtsjärv (Primeval Võrtsjärv by L. Orviku 1958 and K. Orviku 1973). In all likelihood, Lake Small Peipsi already existed at that time and was separated from Ancient Võrtsjärv by a narrow strip of land between Kärevere and Muuge (Fig. 4, points 7 and 8). Depending on the amount of precipitation, the level of Ancient Võrtsjärv must have been seasonally highly fluctuating in the course of years. As a result of wave action and currents, the earlier accumulated glaciofluvial clays and pelitic silts were covered by sands. In places fine sediments were entirely washed away. The bedrock and till, rich in coarse fractions, were exposed once again.

Ancient Võrtsjärv was shallow and its water table was very unstable. A large area was inundated in the depression, mostly during spring floods. By the end of summer, however, only many smaller water bodies remained of it. In the sediments of this lake, pollen grains have preserved only in the loamy silts overlying the varved clays of Ice Võrtsjärv. As we have stated before, the first results of our analyses support the conviction that the preserved pollen grains of the Older Dryas, Allerød, and Younger Dryas have usually all got mixed up. Namely, up to now, we have not succeeded in getting a cross-section with clearly laminated lake sediments near Kärevere to elucidate the chronological as well as sedimental boundary between Ancient and Big Võrtsjärv.

\section{THE HOLOCENE HISTORY OF LAKE VÕRTSJÄRV}

K. Orviku (1973) considers the beginning of the Holocene, which is recorded by the appearance of fossils of higher biota (e.g. mollusc shells in lake sediments), to be a boundary between Ancient Võrtsjärv and Great Võrtsjärv. He named the Early Holocene lake Great Võrtsjärv, because he assumed that due to the land uplift on the so-called Tänassilma threshold established by Lõokene (1960) the lake level must have risen in the course of years. According to K. Orviku 
(1973), the rocks of the Tänassilma threshold, which were rather resistant to erosion, must also have contributed to the process. Lõokene (1960) and K. Orviku (1973) were evidently misguided by Tammekann (1939) who maintained that Lake Viljandi was situated at a height of $43 \mathrm{~m}$ (must be $41 \mathrm{~m}$ ) and the Parika watershed connecting the Navesti Valley and the Võrtsjärv Depression, at a height of $51 \mathrm{~m}$ a.s.l. (must be $42 \mathrm{~m}$ ) (see also Fig. 5 in the present paper). Obviously, Tammekann got these erroneous figures when he transferred the isohypses given in inches on the topographic maps of the General Staff of Russia to the metric system. Surely he was not aware of it when using the map he determined the height of the watershed to be $51 \mathrm{~m}$ at Parika and $45 \mathrm{~m}$ a.s.l. at Järtsaare. Before the bog began to form, the waters were flowing from big ancient Lake Parika along several creeks to the south towards the Tänassilma River. The depression of ancient Lake Parika was overgrown with peat, and bogs were spread there (Fig. 4, point 12). The northward outflow from the Parika Depression took place only after the formation of the raised watershed bog there. The outflows from the bog have considerably been deepened by human activity.

We have been successful in elucidating the Holocene history of Võrtsjärv. The results of our long-term fieldwork are summarized in Fig. 5. The results obtained on the southern part of Võrtsjärv by earlier researchers (L. Orviku 1958; Pirrus et al. 1993) did not entirely satisfy us, because their palynological sections were based on the Holocene sediments deposited in the ancient channel of the VäikeEmajõgi River (see Figs. 4, 8).

It should be pointed out that paludification and overgrowing of old river channels reflect the evolution of a lake and the rise of its water level only indirectly. Our attempts to determine the location of the section described by L. Orviku (1958) on the opposite coast of the lake failed (see Fig. 4, point 10). But drilling with a Belarus-type corer in the lake bottom southeast of the former Naritsa farmhouse revealed the western slope of a rather flat drumlin-like

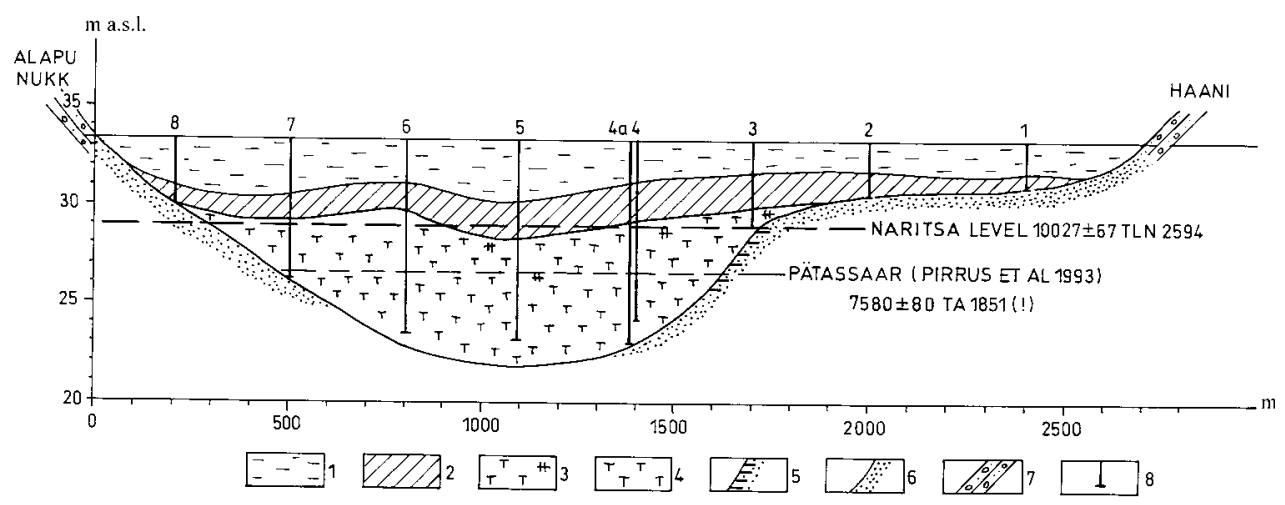

Fig. 8. Geological profile between Haani and Alapu Nukk in the southern part of Lake Võrtsjärv after Pirrus \& Raukas (1984) with complements: 1, water; 2, gyttja (sapropel); 3, sapropelic lime and limy sapropel; 4, lacustrine lime; 5 , silty sand; 6 , sand; 7, till; 8, main boreholes. 
formation, where the remains of ancient paludified soil were lying between the layers of fine gravel and coarse sand. The sample taken from this soil at a height of $29 \mathrm{~m}$ a.s.l. yielded a ${ }^{14} \mathrm{C}$ age of 10027 years (see Fig. 4, point 9 and Fig. 5, point 9).

Under bog sediments we discovered old outflows from the Võrtsjärv Depression into the Navesti River valley (Fig. 4, points 1,2,13). Since loose sediments have mostly been washed away with the flow on the ancient rapids, the ${ }^{14} \mathrm{C}$ dates yielded by plant remains on the exposed limestone bedrock do not show the time when the outflows existed but the time when they were closed and overgrown by peat. Based on the ${ }^{14} \mathrm{C}$ date of $6985 \pm 60$ years (Tln-2627) obtained on the lowermost layer of peat on the limestone, the outflow from the Võrtsjärv Depression to the west closed about $7000{ }^{14} \mathrm{C}$ years ago.

Hopefully, the reader will understand why the numerical values in Figs. 4 and 5 are presented in a rather generalized manner. This enables us to keep within the bounds of reliability and avoid drawing inconsiderate conclusions. For instance, the land uplift gradient presented in Figs. 4 and 5 for the last 10000 years of the Vorrtsjärv Depression is supported by the idea that c. 10000 years ago the lake waves buried a paludified soil layer under sand. In all likelihood, this happened due to the circumstance that the c. $300 \mathrm{~m}$ wide thresholds (rapids) near the Navesti railway bridge and between Järtsaare and Paenaste (Figs. 4, 5, points 1 and 2) had risen almost to the same height as the buried soil at Naritsa. Figure 8 shows to which extent the valley, eroded by the moving ice and its meltwaters in the southern part of the Vorrtsjärv Depression, has filled with sediments. Also above the Naritsa section the sand, rich in organic remains, is overlain by pelitic lake lime and mud. Under the conditions of the fluctuating water level, the older and younger sediments have constantly got mixed during their accumulation. The uplift gradients obtained as a result of our studies permit an approximate estimation of the land uplift on the coasts of the Gulf of Riga and Lake Peipsi. In other words, the results of the study of Võrtsjärv are now comparable with those on the Pärnu Lowland and Peipsi Depression.

The development of Võrtsjärv in the Holocene can be studied in more detail on the basis of its bottom sediments. In the northernmost part of the lake the bottom deposits consist mostly of fine sand and silt. Sapropel and lacustrine lime have not been found there. In the narrower southern part the sediments from top downwards are as follows: sapropel (up to $3 \mathrm{~m}$ ) and lacustrine lime (up to $8 \mathrm{~m}$ thick). The boundary between the sapropel and lime is transitional and asynchronous in different parts of the lake (Figs. 3, 4, point 11 and Fig. 8).

In the Early Holocene, the land surface above the rapids of the westward outflow (Fig. 4, points 1 and 2) into the Navesti River rose at a rate of about a metre per thousand years (Fig. 5). Thus, Big Võrtsjärv was generally a transgressive body of water. Some 8300 years ago, the northern part of the lake basin extended almost as far as the present-day Kamari hydropower station, up to the then mouth of the Põltsamaa River. In the years of great floods, the sediments carried by the 
lake waters clogged the river mouth. The drowned wood $-8400 \pm 100{ }^{14} \mathrm{C}$ years (TA-2706) - in the channel got covered with a $1.5 \mathrm{~m}$ thick layer of sand. At the present time, the surface of this sand is at a height of c. $43 \mathrm{~m}$ a.s.l. (Figs. 4 and 5, point 3). When the water level of Big Võrtsjärv was at that height, an additional outflow must have developed to the east between Kärevere and Muuge (Fig. 4, points 7 and 8).

The palynological studies conducted by Reet Pirrus (Pirrus \& Raukas 1984) in the southern part of the lake - Alapu Nukk - Haani section (Fig. 4, point 11 and Fig. 8) showed that the slightly limy clayey silt containing up to $79 \%$ terrigenous material accumulated at the beginning of the Pre-Boreal. In the second half of the Pre-Boreal and in the Boreal, an about $1 \mathrm{~m}$ thick layer of lacustrine lime, with the $\mathrm{CaCO}_{3}$ content of $70 \%$ and organic matter content of $3-18 \%$ was formed. In the Atlantic Chronozone, about $5.5 \mathrm{~m}$ of lacustrine lime accumulated. At the beginning of the Atlantic, the content of $\mathrm{CaCO}_{3}$ was higher (60-65\%) than at the end of the Chronozone (45-50\%). The organic matter content was 10-15\% and $20-30 \%$, respectively. The amount of organic matter rises upwards, reaching $32 \%$. In the Sub-Boreal, both the organic matter (up to 37\%) and terrigenous component increase, and the deposits in the vertical section are rather heterogeneous. In the Sub-Atlantic Chronozone, sapropel (gyttja) with a rather high content of terrigenous material and a very low content of carbonaceous matter (only 1-2\%) accumulated.

Zur Mühlen (1918) came to the conclusion that Big Võrtsjärv was much larger than the contemporary lake. According to him, the shoreline was at its entire length $4 \mathrm{~m}$ higher than nowadays. Based on the Holocene crustal movements, Ramsay (1929) reached the conclusion that in the northern part of the ancient lake the water level must have been about $5 \mathrm{~m}$ lower than at present. According to K. Orviku (1973), the water level in the NW part of the lake was about 4-5 m higher and in the southern part 3-4 m lower than nowadays. Pirrus et al. (1993) demonstrated that at the beginning of the Holocene the shoreline in the southern part of the lake was even $8 \mathrm{~m}$ lower than at present. To our mind, this value is a bit exaggerated. The zero level of present-day Võrtsjärv equals $33.07 \mathrm{~m}$ a.s.l. According to our calculations, the southern end of the lake was c. $4 \mathrm{~m}$ lower 10000 years ago (see Fig. 8).

\section{THE HISTORY OF THE CONTEMPORARY LAKE}

The beginning of Contemporary Võrtsjärv is traditionally accepted as the time when the outflow to the west finally closed. So far, this event has not been precisely dated. The end of Big Vorrtsjärv is marked with the opening of the outflow to the east via the Emajõgi Valley some 7500 years ago, which was followed by the lowering of lake level (K. Orviku 1973). We have not succeeded in dating the formation of the Emajõgi River. About 10000 years ago, when our 
sampling sites at Navesti and Naritsa were at the same level (Fig. 5), the strip of lowland between Kärevere and the mouth of the Amme River at Muuge was only $1.5 \mathrm{~m}(\max 2.0 \mathrm{~m})$ above the level of Võrtsjärv. At that time, the Amme River flowed into Small Peipsi. Actually, already in this period, during some extreme years, the water from Vorrtsjärv may have flowed through the woods into the Amme River. As the water had to curve through coarse till and glaciofluvial sediments and the erosion-resistant Middle Devonian sandstones of Narva age $\left(\mathrm{D}_{2} \mathrm{nr}\right)$, the formation of the channel lasted thousands of years.

The palynological evidence from Põltsamaa Bog northeast of the lake suggested already some 40 years ago that the water table started to lower in the $\mathrm{BO}_{2}$ palynozone (Zirna \& Pirrus 1961). At the beginning of the Middle Holocene, a more pronounced lowering occurred. In Ulila Bog, northeast of the lake, the uppermost deposits were dated at $6915 \pm 70 \mathrm{yr}$ BP (TA-120, Ilves \& Sarv 1970). The lake marl gave a much older radiocarbon date of $7800 \pm 260 \mathrm{yr}$ BP (TA-3) and referred that event to the very beginning of $\mathrm{AT}_{1}$ (Liiva et al. 1966). Up to now, the exact time of the event is uncertain. It is more or less certain that a new outflow to the east via the Emajõgi channel was finally formed in the Atlantic Chronozone some 7500 years ago (Table 1), the water level sank and a lake, similar to the contemporary one, was born. However, during spring floods extensive areas in the ancient lake depression were again inundated, and so the development of the contemporary lake was a long and complicated process.

The Holocene development of Võrtsjärv has been highly controlled by tectonic movements. While the northern part of the lake was subject to a marked regression, the structure of the geological sections, intensive overgrowing and meandering of the lower reaches of rivers in the southern part of the lake prove that the water table rise there was continuous. It was not interrupted even at the beginning of the Middle Holocene. At the same time, synchronous water level changes in the small lakes of the adjoining area and in Võrtsjärv were due to climatic changes (Saarse \& Harrison 1992). The Estonian small lakes register wetter conditions from $8000 \mathrm{BP}$, with the maximum humidity at $7000 \mathrm{BP}$. The maximum aridity occurred at $4000 \mathrm{BP}$.

Võrtsjärv is characterized by a variety of shore types. Due to the prevailing westerly and southwesterly winds, accretional and erosional shores dominate in the eastern, leeward part of the lake. The western shore is swampy, overgrown with bulrush and reed, which occasionally form $40 \mathrm{~m}$ and wider belts on the foreshore. Due to the shallowness of the lake and unstable shoreline, erosional forms are relatively small in size. When the lake level was low, there was practically no erosion (Fig. 9). The erosion intensified during the high lake level (Fig. 10). In the course of our study period (since 1982), the coast has retreated only a few metres (Fig. 11) and not everywhere. Compared to wave action, the hummocky coastal ice has exerted even a greater effect on the coastal processes. Longshore drift is low, but in the 19th century the sand repeatedly clogged the outflow of the Emajõgi River and caused severe floods. 


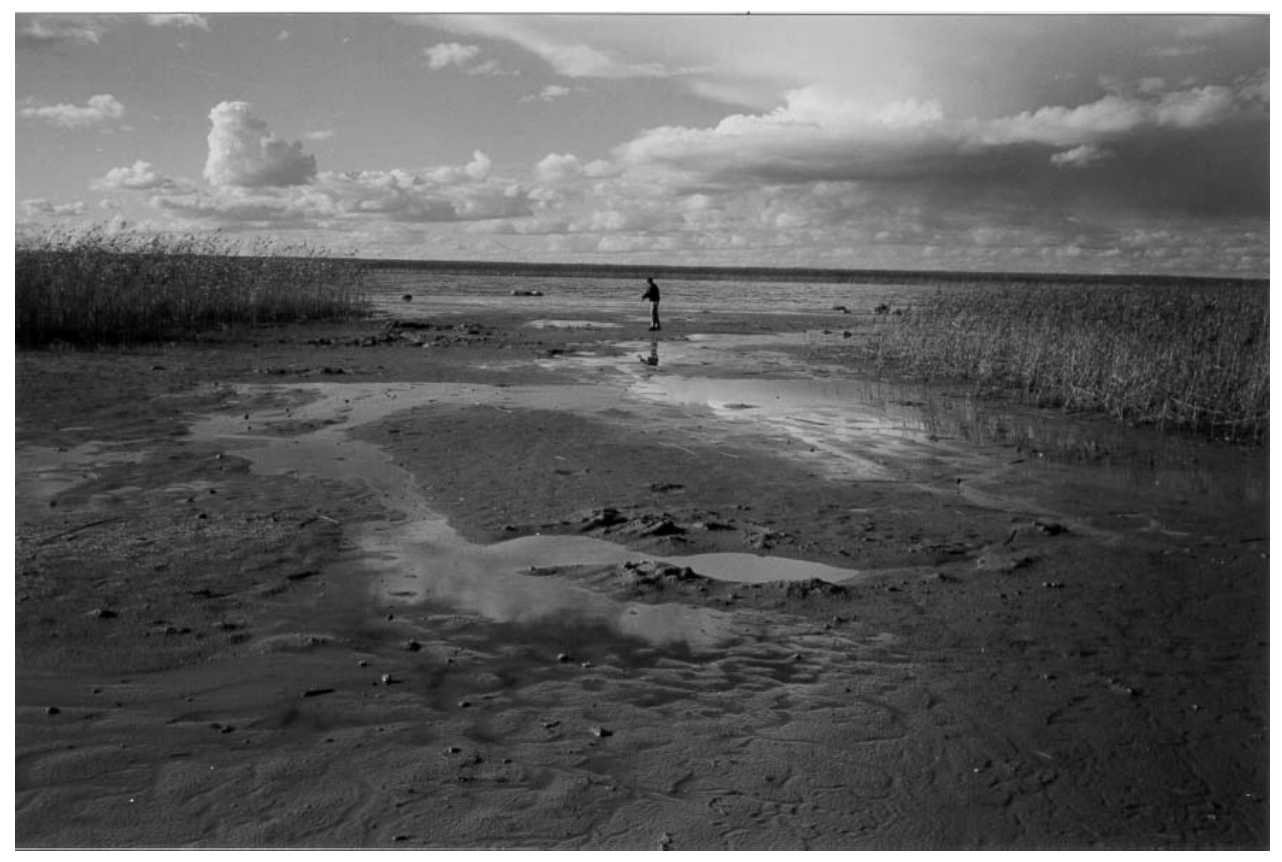

Fig. 9. Eastern shore of L. Võrtsjärv during a low stand of water on 06.06.2001. Photo by A. Raukas.

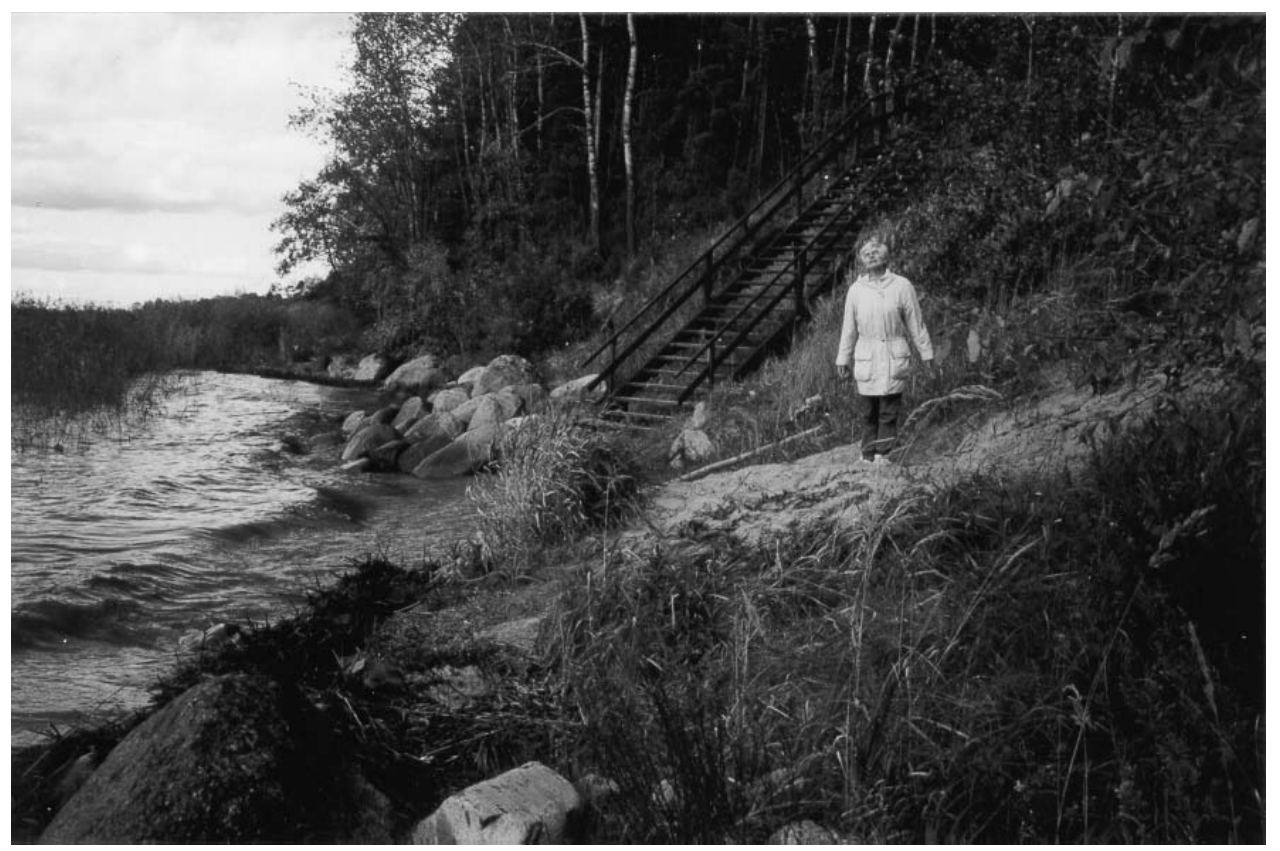

Fig. 10. Eastern shore of L. Võrtsjärv during a high stand of water on 15.09.1998. For location of the section see Fig. 1. Photo by A. Raukas. 


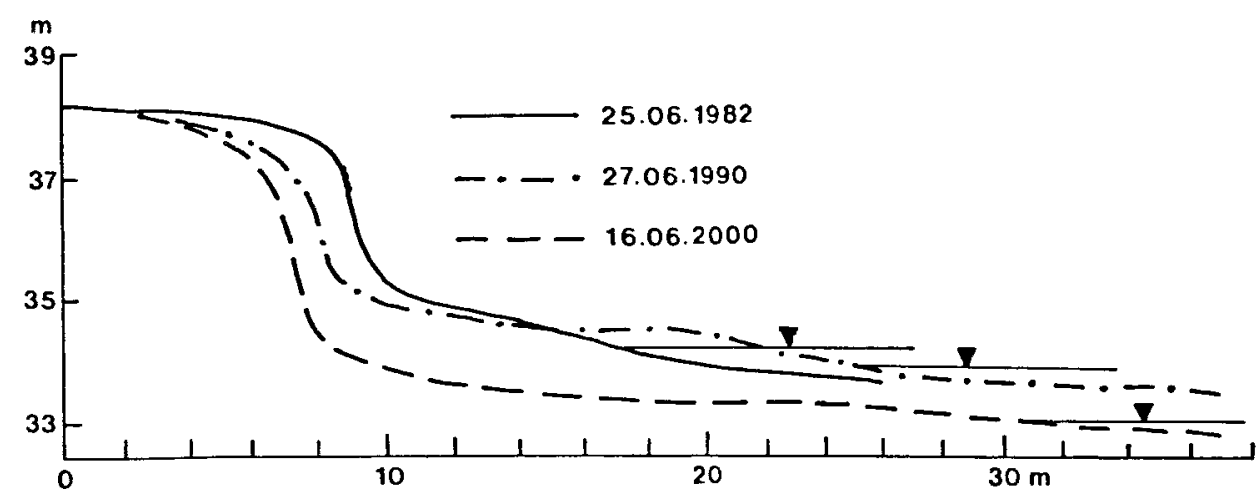

Fig. 11. Curves showing beach dynamics near Petseri on 25.06.1982, 27.06.1990, and 16.06.2000.

\section{ACKNOWLEDGEMENTS}

We are obliged to late Reet Pirrus, a good colleague, who participated in our studies from the very beginning. Our thanks also go to Helle Kukk who typed and made the preliminary revision of the manuscript, to Kersti Kihno for the unpublished palynological diagram, to Rein Vaher, Katrin Erg, and Kersti Siitan for their kind assistance with the drawings. The research was financed by the Estonian Science Foundation - grant No. 4046 "Geological Development of Lake Võrtsjärv" to Anto Raukas and grant No. 4195 "Impact of the Environmental Conditions on the Stone Age Settlement in South-West Estonia and in the basin of Lake Võrtsjärv" to Tanel Moora. The valuable comments and recommendations of the referees Avo Miidel and Vitalijs Zelčs are greately appreciated.

\section{REFERENCES}

Aboltynsh, O. P. 1971. Development of the River Gauja Valley. Zinatne, Riga (in Russian).

Aboltynsh, O. P.,Veinbergs, I. \& Eberhards, G. 1974. On the formation of pre-frontal glaciofluvial basins and river network during the degradation of the ice sheet of the last glaciation on the territory of the Latvian SSR. In Predfrontal'nye kraevye obrazovaniya (Biske, G. \& Mikalauskas, A., eds.), pp. 60-85. Mintis, Vilnius (in Russian).

Hang, T. 2001. Local clay-varve chronology and proglacial sedimentary environment in glacial Lake Peipsi, eastern Estonia. Quaternaria, Ser. A, No. 11. Paper V, 1-14.

Ilves, E. \& Sarv, A. 1970. Stratigraphie und Chronologie der See und Torfablagerungen des Moores Ulila (Mittel-Estland). ENSV TA Toim. Keemia Geol., 19, 135-140 (in Russian).

Jaani, A. 1973. Hüdroloogia. In Võrtsjärv (Timm, T., ed.), pp. 37-60. Valgus, Tallinn.

Kajak, K. 1959. Die Geologie des Väike-Emajõgi-Tales. TRÜ Toim., 75, 155-184 (in Russian).

Kents, P. 1939. Postglatsiaalsed Läänemere rannajoone võnkumised Eestis illustreeritud Kõpu poolsaarel. Master's thesis (manuscript), Institute of Geography, University of Tartu. Tartu. 
Kessel, H. 1961. Ancient coastal formations of the Baltic on the territory of the Estonian S.S.R. ENSV TA. Geol. Inst. Uurimused, 8, 113-131 (in Russian).

Kessel, H. \& Raukas, A. 1979. Estonia. In The Quaternary History of the Baltic (Gudelis, V. \& Königsson, L.-K., eds.). Acta Univ. Upsaliensis. Symp. Univ. Upsaliensis. Annum Quingentesimum Celebrantis, 1, 127-146.

Liiva, A., Ilves, E. \& Punning, J.-M. 1966. Verzeichnis der im Institut für Zoologie und Botanik der Akademie der Wissenschaften der Estnischen SSR Mittels der Radiokohlenstoff-Methode Datierten Proben. ENSV TA Toim. Biol., 1, 112-121 (in Russian).

Lõokene, E. 1960. Sakala kõrgustiku orgude geoloogiast. Eesti Loodus, 2, 72-81.

Orviku, K. 1973. Võrtsjärve geoloogilisest arengust. In Võrtsjärv (Timm, T., ed.), pp. 26-32. Valgus, Tallinn.

Orviku, L. 1958. Neue angeben über die Geologie des Sees Wõrtsjärw. ENSV TA Geol. Inst. Uurimused, 3, 269-293 (in Russian).

Pirrus, R. \& Raukas, A. 1984. Uusi andmeid Võrtsjärve geoloogiast. In Võrtsjärve ökosüsteemi seisund (Haberman, J., ed.), pp. 15-24. ENSV Teaduste Akadeemia, Tartu.

Pirrus, R. \& Raukas, A. 1996. Late-Glacial stratigraphy in Estonia. Proc. Estonian Acad. Sci. Geol., 45, 34-45.

Pirrus, R., Hang, T. \& Liiva, A. 1993. On the geological development of the Väike-Emajõgi Valley and the southern part of Lake Võrtsjärv. Proc. Estonian Acad. Sci. Geol., 42, 28-37 (in Russian).

Pärna, K. 1962. About the geology of the Baltic Ice Lake and large local glacial lakes in the territory of Estonia. Tartu, Manuscript, Central Archives of the Estonian Academy of Sciences, fund 16,3, item 668 (in Russian).

Ramsay, W. 1929. Niveauverschiebungen, eisgestaute Seen und Rezession des Inlandeises in Estland. Fennia, 52, 1-48.

Raukas, A. 1986. Deglaciation of the Gulf of Finland and adjoining areas. Bull. Geol. Soc. Finland, 58, Part 2, 21-33.

Raukas, A. \& Tavast, E. 1990. Võrtsjärv. Nõo geoloogiline ehitus ja järve arengulugu. Eesti Loodus, 11, 697-747.

Raukas, A., Rähni, E. \& Miidel, A. 1971. Marginal Glacial Formations in North Estonia. Valgus, Tallinn (in Russian).

Raukas, A., Saarse, L. \& Veski, S. 1995. A new version of the Holocene stratigraphy in Estonia. Proc. Estonian Acad. Sci. Geol., 44, 201-210.

Rumma, I. 1923. Viljandi oru veelahe. Loodus, 1, 31-53.

Saarse, L. \& Harrison, S. P. 1992. Holocene lake-level changes in the Eastern Baltic region. In Estonia. Man and Nature (Kaare, T., Mardiste, H., Merikalju, L. \& Punning, J.-M., eds.), pp. 6-20. Estonian Geogr. Soc., Tallinn.

Stelle, V., Yakubovska, I. \& Savvaitov, A. 1995. Pollen Complexes of Late- and Post-Glacial sediments in the Gulf of Riga. Baltica, 8, 38-42.

Tammekann, A. 1932. Valga. Ase. In Eesti V. Valgamaa, pp. 479-484. Tartu.

Tammekann, A. 1939. Viljandimaa pinnaehitus. In Eesti VII. Viljandimaa, pp. 4-10. Tartu.

Tarvel, E. (ed.). 1982. Henriku Liivimaa kroonika. Eesti Raamat, Tallinn.

Tavast, E. 1998. Coastal monitoring of Estonia's large lakes. In Estonian Environmental Monitoring, pp. 118-121. Estonian Ministry of Environment, Environmental Information Centre, Tallinn.

Tavast, E. \& Raukas, A. 1982. The Bedrock Relief of Estonia. Valgus, Tallinn (in Russian).

Varep, E. 1958. Võrtsjärv. Füüsilis-geograafiline ülevaade ja uurimise ajalugu. Hüdrobioloogilised uurimused, 1, 146-151 (in Russian).

Zirna, E. \& Pirrus, R. 1961. Õietolmuanalüüsi tulemustest Kirde- ja Kesk-Eesti holotseensetest setetest. ENSV TA Geol. Inst. Uurimused, 7, 95-104.

zur Mühlen, L. 1918. Geologie und Hydrologie des Wirzjerv Sees. Abhandl. Preuss. Geol. Landesanst., Neue. Folge, H.83, 14-92. 


\title{
Võrtsjärve geoloogilisest arenguloost
}

\author{
Tanel Moora, Anto Raukas ja Elvi Tavast
}

Võrtsjärve keskse asendi tõttu Eesti maa-alal on tal oluline koht paljude hilisjääaja ja jääajajärgsete paleogeograafiliste probleemide lahendamisel. Võrtsjärve varasemad arenguetapid Jää-Võrtsjärv, Ürg-Võrtsjärv ja Suur-Võrtsjärv on paljuski hüpoteetilised, nende kontuurid täpsemalt määratlemata ja ajalised piirid vaieldavad. Nüüdis-Võrtsjärve alguseks võib pidada 7500 aastat, kui väljavool Peipsi suunas oli välja kujunenud. Suur järvelubja $(8 \mathrm{~m})$ ja sapropeeli $(9 \mathrm{~m})$ paksus järve lõunaosas viitavad veetaseme järkjärgulisele tõusule selles piirkonnas kogu Holotseeni vältel. Järsk veetaseme muutus ja järve ulatuse varieeruvus erinevatel arenguetappidel olid põhjustatud peamiselt maakoore tektoonilistest liikumistest, mis avasid uusi ja sulgesid varasemaid välja- ning sissevoole. Nii möödanikus kui ka praegu olid järves suured veetaseme kõikumised, mis raskendavad rannajoonte ja jõeterrasside rööbistamist.

\section{О геологическом развитии озера Выртсъярв}

\author{
Танел Моора, Анто Раукас и Эльви Таваст
}

Ввиду своего расположения в центре Эстонии (рис. 1) озеро Выртсъярв имеет важное значение для решения многих существенных проблем позднеи послеледниковья. Озёрная впадина в своём первичном виде образовалась ещё в дочетвертичное время, но современный облик она приобрела благодаря ледниковой эрозии. Донные отложения озера представлены терригенными осадками, сапропелем (мощностью до 9 м) и озёрной известью (до 8 м). Последние в северной части впадины маломощные или отсутствуют. Мощность осадков в южной части впадины значительно больше, чем в северной, что говорит о наступании озера в южном направлении.

История развития озера сложная. Непосредственно перед краем ледника образовались озёрно-ледниковые водоемы различной конфигурации и размеров. В раннем голоцене, благодаря неравномерному (на северо-западе больше юго-восточного) неотектоническому поднятию земной коры сток в западном направлении перекрывался, что привело к образованию озера Большой Выртсъярв, уровень которого был на 4-5 м выше, чем в современном озере. В среднем голоцене, около 7500 л. н. образовался сток в восточном направлении по р. Эмайыги, и озеро постепенно приобрело современные очертания. Уровень воды в озере как ныне, так и в прошлом весьма непостоянный (максимальная разница водного зеркала в прошлом столетии была около 3 м), что затрудняет корреляцию береговых линий, речных террас и восстановление истории геологического развития озера. 